Egyptian Journal of Aquatic Biology \& Fisheries

Zoology Department, Faculty of Science,

Ain Shams University, Cairo, Egypt.

ISSN $1110-6131$

Vol. 24(4): 321 - 340 (2020)

www.ejabf.journals.ekb.eg

\title{
Antimicrobial activity of some Egyptian marine invertebrates, Red Sea
}

\author{
Hassan A. H. Ibrahim ${ }^{1}$, Dalia E. Elatriby ${ }^{2}$ and Moaz M. Hamed ${ }^{1 *}$ \\ ${ }^{1}$ Microbiology Department, National Institute of Oceanography and Fisheries (NIOF), Egypt. \\ ${ }^{2}$ Microbiology Department, Specialized Medical Hospital, Mansoura University, Egypt. \\ *Corresponding Author: Moaz-micro@ hotmail.com
}

\section{ARTICLE INFO \\ Article History: \\ Received: April 6, 2020 \\ Accepted: June 25, 2020 \\ Online: June 28, 2020}

Keywords:

Antimicrobial activity,

Invertebrates,

Sea cucumber,

Sponge,

Red Sea.

\begin{abstract}
Three species of sponge and one species of sea cucumber representative to marine invertebrates were collected from the Red Sea, Hurghada, Egypt. They were identified based on general morphological and anatomical features as Cinachyrella arabica, Ciocalypta penicillus, Axinella verrucosa, and Holothuria atra. Their antibacterial and antifungal activities in crude extracts were investigated and data revealed that the positive values were recorded in the range of 8 to $20 \mathrm{~mm}$ by the ethyl acetate crude extract obtained from C. arabica. E. coli was the most affected bacterium followed by $S$. typhimurium that was $18 \mathrm{~mm}$ by the ethyl acetate crude extract obtained from A. verrucosa. Also, the fungal suppression \% was in the range of 10$100 \%$ by all kinds of sponge crude extracts. However, the ethanolic extract of $C$. arabica and ethyl acetate extract of $C$. penicillus had the highest suppression \%, followed by the ethanolic extract of C. penicillus as of $90 \%$. Likewise, the highest activity was detected by $H$. atra methanolic crude extract against $A$. hydrophila, followed by the same extract against $S$. aureus $(14 \mathrm{~mm})$. Only $P$. notatum was the fungus that affected by both ethanolic and methanolic extracts with $20 \%$ suppression. On the other side, results of GCMS/MS of crude extract observed the presence of several bioactive constituents, most of which had antimicrobial activities.
\end{abstract}

\section{INTRODUCTION}

The multi-resistant nature of pathogens to antibiotic is the serious threat and has stimulated search for novel antimicrobial agents from various natural sources (Abubakar et al., 2012). The resistance to current antibiotics remains a significant challenge for pathogenic bacterial infections (Mayer et al., 2007). Therefore, the search for alternative antimicrobial agents from alternative sources became an essential demand. It is widely 
accepted that new drugs, especially antibiotics, and that the most propitious source remains natural products (Bull and Stach, 2007; Mayer et al., 2007).

During the last decade, there has been an increase in research on marine crustaceans, molluscs, and echinoderms, particularly interest on their secondary metabolites with desirable antimicrobial properties (Casas et al., 2011). Many of these organisms produce their antibacterial factors as a first line of defense against pathogenic microbes (Haug et al., 2002).

On the other hand, sponges are the most well studied animals among the marine invertebrates, from which a vast array of bioactive compounds have been isolated (Hu et al., 2015). Actually, they are considered as the chemical factory in marine environment because of its immense production of chemically diverse compounds. Other than the chemical diversity, these compounds possess remarkable bioactivities (Kim and Dewapriya, 2012). Also, they were considered for years as a rich source of natural products and metabolites for antibiotics with strong inhibitory activity against bacteria, fungi and microbes Research showed that many bioactive compounds from various sponge species can be useful for the development of new antibiotics and antimicrobial drugs (Shen et al., 2012). Specifically, Youssef et al. (2013) identified three new alkaloids from the Red Sea sponges which displayed antimicrobial activity against several pathogens, antioxidant activity and cancer growth inhibition activities. However, they concluded the importance of drug leads from Red Sea sponges.

Echinoderms have been, and continue to be, examined as a source of biologically active compounds with biomedical applications. Sea cucumber has been valued in Chinese medicine for hundreds of years as a cure for a wide variety of ailments (Kelly, 2005). Some more recently isolated compounds, mainly from sea cucumbers including those with antitumor, antiviral, anticoagulant, anti-angiogenic, anticancer, antihypertension, anti-inflammatory, antimicrobial, antioxidant, antithrombotic, antitumor and wound healing have been ascribed to various species of sea cucumbers. When wild stocks decline, the demand created in the market place raises to the price of the product and, consequently, culturing is more likely to become viable economically (Jawahar et al., 2002; Althunibat et al., 2009).

Therefore, the current work was suggested to extract and partially characterize, via GC/MS technique, the potent antimicrobial agents from the Red Sea sponges and sea cucumber species.

\section{MATERIALS AND METHODS}

\section{Experimental animals and samples collection}

Sponge and sea cucumber samples were collected from the sites located around Hurghada city, Egypt. The sponge specimens were collected by using SCUBA diving and snorkeling at the depth of $(5-100 \mathrm{~m})$. Sea cucumber specimens with a size range of 10 to $30 \mathrm{~cm}$ in length and 30 to $180 \mathrm{~g}$ weight were collected manually from the intertidal zone at the depth of 1-5 m. All fresh samples were then washed with seawater at the sampling 
site to remove the adhered sediments and impurities, and then put in polyethylene bags. Quick rinsing of the samples with tap water was done in the laboratory on the same day to get rid of the remaining impurities and epiphytes.

\section{Reference microbes and culture media}

During this work, there five Gram positive bacterial pathogens (Bacillus subtlis ATCC 6633, B. cerues, Staphylococcus aureus ATCC 25923, Staphylococcus epidermids, Enterococcus faecalis ATCC 29219) besides three Gram negative bacterial ones (Pseudomonas aeruginosa ATCC 9027, Escherichia coli ATCC 8739) Aermonas hydrophila, and Vibrio damsela were used as reference strains. Also, there one yeast species (Candida albicans) was used as reference strains. As well as, there seven fungal pathogens (Penicillum crustosum, Penicillum notatum, Aspergillus terreus, Aspergillus niger, and Fusarum solani). Some of these strains were kindly provided from Microbiology Laboratory (National Institute of Oceanography and Fisheries, Alexandria, Egypt). Some others purchased from the Center of Fungi, Asuit University, Egypt.

On the other side, three common media were used to culture the reference strains and determine the antimicrobial activity of sea hare extract as follows: i) Nutrient broth (NB) and nutrient agar (NA) (Atlas, 1997) were used in all microbiological tests. Bacterial inocula was prepared by inoculating $100 \mathrm{ml}$ of nutrient broth medium, and incubated in a shaker $(250 \mathrm{rpm})$ at $30^{\circ} \mathrm{C}$ for $24 \mathrm{~h}$ until the late logarithmic phase of growth $\left(\mathrm{A}_{550}=1\right)$. ii) Sabouraud dextrose agar; (SDA) (Guinea et al., 2005) was used to cultivate yeast and other types of fungi. iii) Potato dextrose broth PDB and potato dextrose agar (PDA) (Atlas, 1997) were used to culture yeasts such as $C$. albicans and Saccharomyces cerevisiae and molds such as A. niger.

\section{Extraction of antimicrobial agents}

The samples of all marine invertebrates were cut into very small pieces of about 2 $\mathrm{mm}$ size. The extraction was carried out with four organic solvents; acetone, aqueous ethanol (70\%), ethyl acetate, and methanol by soaking the material in the respective solvents $(1: 10, \mathrm{w} / \mathrm{v})$ on a rotary shaker at $150 \mathrm{rev} \min ^{1}$ at ambient temperature for $96 \mathrm{~h}$. The extract from consecutive soaking was pooled and filtered using filter paper (Whatman no 4). After evaporation of the solvent, the crude extract was re-suspended in $5 \mathrm{ml}$ of dimethyl sulphoxide (DMSO). The antibacterial efficiency of the tested extract in DMSO was screened against different microbial pathogens.

\section{Antibacterial and anti-yeast bioassay}

All reference strains of bacteria and yeasts were examined as pathogens. A volume of $15 \mathrm{ml}$ of the sterilized nutrient agar for bacteria and Sabouraud dextrose agar for yeast were poured into sterile caped test tubes and were allowed to cool to $50^{\circ} \mathrm{C}$ in a water bath. A half of $\mathrm{ml}$ of inocula $\left(10^{8} \mathrm{CFU}\right.$ for bacteria and yeast) were added. The 
tubes were mixed using a vortex for 15-30 s. Thereafter, each test tube contents were poured onto a sterile $100 \mathrm{~mm}$ diameter Petri dish for solidification (Khan et al., 2019). The activity was evaluated using well-cut diffusion technique. Wells were punched out using a sterile $07 \mathrm{~cm}$ cork-porer in nutrient agar plates containing the tested microorganisms. About $100 \mu \mathrm{l}$ of each crude extract were transferred into each well. They were subjected to $4{ }^{\circ} \mathrm{C}$ incubation for $2 \mathrm{~h}$, and then were later incubated at $37^{\circ} \mathrm{C}$ for $24 \mathrm{~h}$. The results were obtained by measuring the diameter of inhibition zone three times for each well and expressed in millimeter (Amer and Ibrahim, 2019).

\section{Antifungal bioassay}

\section{By pouring technique}

The crude extracts were tested against the indicator fungi by adding aliquots of it to PDA medium at a concentration of $10 \%(\mathrm{v} / \mathrm{v})$. One disc of the seven fungal growths was separately placed on the center of a plate containing crude extract-PDA medium. All plates were incubated at $28^{\circ} \mathrm{C}$ until the control was completely covered with fungal growth. The radius-growth of each indicator fungus was measured to estimate the suppressive eff ect $(\%)$ of crude extract against the indicator fungi (Amer and Ibrahim, 2019).

\section{By well-cut diffusion technique}

One disc of the five fungal growths was separately put on the top of a plate containing PDA medium. About $100 \mu \mathrm{l}$ of each crude extract were transferred into each well. All plates were incubated at $28^{\circ} \mathrm{C}$ until the control was completely covered with fungal growth. The results were obtained by measuring the inhibition zone diameter three times for each well and expressed in millimeter (Amer and Ibrahim, 2019).

\section{Antibiotic susceptibility test}

Five commercial antibiotics: Cephalexin (CL, $30 \mu \mathrm{g})$, Rifampicin (RF, $30 \mu \mathrm{g}$ ) Piperacillin (TZP, $10 \mu \mathrm{g}$ ) Metronidazole (MTZ, $20 \mu \mathrm{g}$ ), and Amikacin (AMK, $30 \mu \mathrm{g}$ ) were selected to test their inhibition capacity against the bacterial strains besides the yeast strain $C$. albicans. The microbial strains were inoculated in the sterilized prepared medium. Instead of the crude extract of marine invertebrates, small discs of the five antibiotics were put associated with each microbial strain. All plates were subjected to $4^{\circ} \mathrm{C}$ incubation for $2 \mathrm{~h}$, and then later incubated at $37^{\circ} \mathrm{C}$ for $24 \mathrm{~h}$ (Khan et al., 2019; Shaaban et al., 2020). The results were estimated by measuring the diameter of inhibition zone three times for each well and expressed in millimeter.

\section{GC-MS/MS analysis of sea star extract}

The different crude extracts were prepared with by soaking the fresh animal material in pure ethanol $(1: 10, \mathrm{w} / \mathrm{v})$ and the filtrate was subjected to gas chromatographymass spectrometry (GC-MS) analysis (Perkin Elmer, Waltham, MA, USA) according to 
(Muller et al., 2002). The analyses were performed in Agilent 7693 series GC system equipped with an OV-5 capillary column (length $30 \mathrm{~m} 9$ diameter $025 \mathrm{~mm} 9$ film thickness 025 lm; Ohio Valley Specialty Chemical, Inc., Marietta, OH, USA) and an Agilent 5975C network selective mass detector, with initial temperature $90^{\circ} \mathrm{C}$ for $1 \mathrm{~min}$, reaching to $300^{\circ} \mathrm{C}$ for $30 \mathrm{~min}$, the splitless mode with injection volume $1 \mu \mathrm{l}$ (total run time $6187 \mathrm{~min})$. The mass spectrometer was operated in the electron impact (El) mode at $70 \mathrm{eV}$ in the scan range $60-600 \mathrm{~m} / \mathrm{z}$. The helium was used as the carrier gas pressurized to $2223 \mathrm{psi}$, whereas the gas flow was $122 \mathrm{ml} / \mathrm{min}$. The chemical constituents of the extract were identified by comparing the GC-MS peaks with retention times of standards, and the mass spectra obtained were compared with those available in the Mass Spectral Library NIST 2015. The percentage of each component was estimated as the ratio of the peak area to the total chromatographic area.

Statistics

The statistical software SPSS 17 was used for statistical analysis. One-way analysis of variance (ANOVA) test was performed to determine the differences between various groups. $\mathrm{P}<0.05$ was considered significant.

\section{RESULTS AND DISCUSSION}

Marine invertebrates are extremely diverse, widely distributed and are always exposed to huge microbial challenges from the oceanic environment which is continuously altering (Otero-González et al., 2010). On the other hand, they are considered a promising field for the discovery of novel drugs. Marine sponges have efficiently provided potent drugs against several critical diseases as cancer, malaria, microbial, viral and many inflammatory diseases (Perdicaris, 2013). Therefore, the current study was suggested to screen three sponge species and one sea cucumber, collected from the Egyptian Red Sea at Hurghada, as a source of bioactive substances, which can be used as antibacterial agents against several human and fish pathogens. The four species of sponges and sea cucumber, collected for the current study, were identified as; Cinachyrella arabica (Carter, 1869), Ciocalypta penicillus (Bowerbank, 1862), Axinella verrucosa (Esper, 1794), and Holothuria atra. All these species have been habited commonly in the Egyptian Red Sea, Hurghada. However, its classification positions and general features of them within Kingdom Animalia are presented in Table 1 and Fig. 1, respectively.

In general, marine sponges (Hegde et al., 2002) and sea cucumbers (Chen, 2003) have capability of providing several antimicrobial agents. Indeed, the extracts of numerous marine invertebrates have shown broad spectra of antibacterial activity. Some of them were obviously active against pathogenic bacteria and yeasts (Marmouzia et al., 2018). However, the antimicrobial effects of the crude extracts obtained from the 
identified four marine invertebrates, including the antibacterial and antifungal activities, were estimated and then expressed in inhibition zone $(\mathrm{mm})$.

Table 1: Classification position of sponges and sea cucumber within Kingdom Animalia.

\begin{tabular}{ccccc}
\hline \multirow{2}{*}{ Position } & \multicolumn{4}{c}{ Sample/scientific classification } \\
\cline { 2 - 5 } & Brown sponge & Yellow sponge & Long finger sponge & Sea cucumber \\
\hline Kingdom & Animalia & Animalia & Animalia & Animalia \\
Phylum & Porifera & Porifera & Porifera & Echinodermata \\
Class & Demospongiae & Demospongiae & Demospongiae & Holothuroidea \\
Order & Spirophorida & Halichondrida & Halichondrida & Holothuriidae \\
Family & Tetillidae & Halichondriidae & Axinellidae & Holothuriida \\
Genus & Cinachyrella & Ciocalypta & Axinella & Holothuria \\
Species & C. arabica $($ Carter, & C. penicillus & A. verrucosa (Esper, & H. atra \\
& 1869) & (Bowerbank, 1862) & 1794) & \\
\hline
\end{tabular}

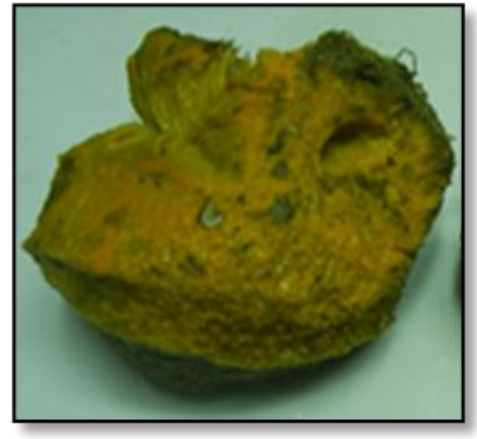

Cinachyrella arabica

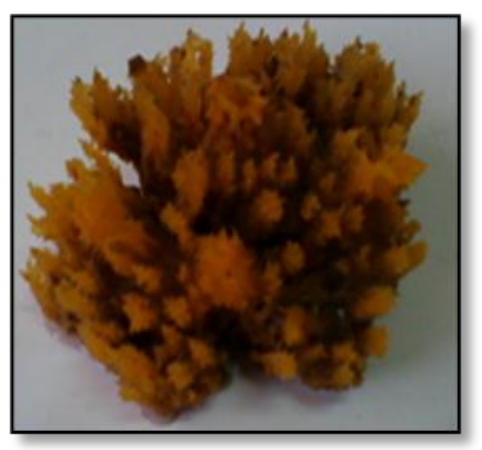

Ciocalypta penicillus

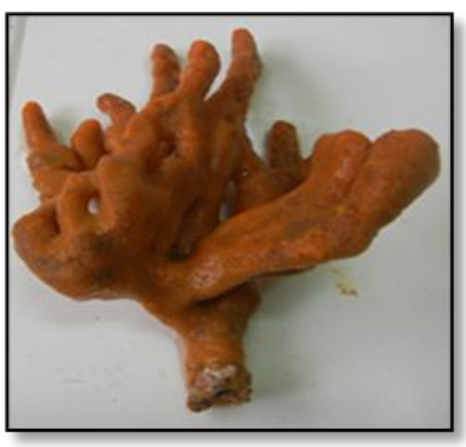

Axinella verrucosa

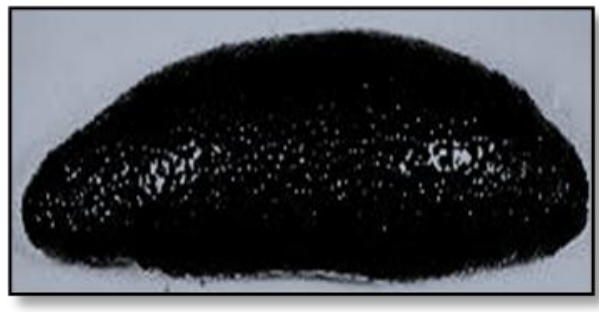

Hololhuria atra

Fig. 1: General features of collected sponges and sea cucumber.

The result in the Table 2 showed that there were rather than fluctuations in the antimicrobial activities values from sponges extracts. Generally, there four pathogenic bacteria were not affected at all, they were; S. aureus, S. epidermids, A. hydrophila, and $V$. fluvialis. The other pathogens were clearly influenced in moderate activities ( 10-14 $\mathrm{mm})$ such as, high activities $(\sim 15-19 \mathrm{~mm})$ or very high activity ( 20 and more). Particularly, the positive values were recorded in the range of 8 to $20 \mathrm{~mm}$. However, $E$. coli was the most affected bacterium by the ethyl acetate crude extract obtained from $C$. 
arabica, followed by $S$. typhimurium that was $18 \mathrm{~mm}$ by the ethyl acetate crude extract obtained from A. verrucosa, etc. Amazingly, different crude extracts of C. arabica were the most potent recording 8 positive activities, while 5 and 4 positive records were detected only for different crude extracts of $A$. verrucosa and $C$. penicillus, respectively.

Similarly, Ibrahim et al. (2018) obtained very high bioactivity values finding that the acetone extract of Spongia sp. was the most effective against $A$. hydrophila $(39.7 \mathrm{~mm})$ followed by ethanol extract $(35.3 \mathrm{~mm})$, while the crude extracts of $C$. penicillus and $A$. verrucosa showed antibacterial activities against $E$. coli were 29.1, 29.1, and $28.0 \mathrm{~mm}$ for ethanol, acetone, and methanol extracts, respectively. Also, Abou-Elela et al. (2009) tested crude extracts of marine sponge against different bacterial pathogens and found that extracts of Spongia officinalis exhibited the highest inhibiting activity. The inhibition zones ranged from $13.0 \mathrm{~mm}$ against $S$. aureus, $S$. faecalis and $P$. aeruginosa to $15.4 \mathrm{~mm}$ against $E$. coli. Besides that, it has been observed that chloroform crude extracts were more effective than those of ethanol crude. Moreover, sponge's chloroform crude extracts acted on inhibiting the growth of all pathogenic bacteria. Extracts from the sponge species Cinachyrella sp., Haliclona sp. and Petromica citrina showed antibacterial activity against $61 \%$ of the coagulase-negative staphylococci (CNS) strains (responsible for causing bovine mastitis), including strains resistant to conventional antibiotics. Extracts from $P$. citrina showed the largest spectrum of inhibitory activity (Laport et al., 2012).

Table 2: Antibacterial activity of different sponges extracts against some reference bacteria.

\begin{tabular}{|c|c|c|c|c|c|c|c|c|c|c|c|c|}
\hline \multirow{3}{*}{$\begin{array}{l}\text { Bacterial } \\
\text { pathogen }\end{array}$} & \multicolumn{12}{|c|}{ Inhibition zone $(\mathrm{mm}) /$ species crude extract } \\
\hline & \multicolumn{4}{|c|}{ Long tree sponge } & \multicolumn{4}{|c|}{ Brown sponge } & \multicolumn{4}{|c|}{ Yellow sponge } \\
\hline & $\mathbf{E}$ & EA & $\mathbf{M}$ & $\bar{A}$ & $\mathbf{E}$ & EA & $\mathbf{M}$ & $\mathbf{A}$ & $\mathbf{E}$ & EA & $\mathbf{M}$ & $\mathbf{A}$ \\
\hline B. subtlis & 0.0 & 0.0 & 0.0 & 0.0 & $\begin{array}{c}10 \\
\pm 0.2\end{array}$ & $\begin{array}{c}14 \\
\pm 1.0\end{array}$ & 0.0 & 0.0 & $\begin{array}{c}11 \\
\pm 0.1\end{array}$ & 0.0 & 0.0 & 0.0 \\
\hline S. aureus & 0.0 & 0.0 & 0.0 & 0.0 & 0.0 & 0.0 & 0.0 & 0.0 & 0.0 & 0.0 & 0.0 & 0.0 \\
\hline S. epidermids & 0.0 & 0.0 & 0.0 & 0.0 & 0.0 & 0.0 & 0.0 & 0.0 & 0.0 & 0.0 & 0.0 & 0.0 \\
\hline E. faecalis & 0.0 & 0.0 & 0.0 & 0.0 & 0.0 & $\begin{array}{c}14 \\
\pm 0.3\end{array}$ & 0.0 & 0.0 & 0.0 & 0.0 & 0.0 & 0.0 \\
\hline P. aeruginosa & $8 \pm 0.7$ & $18 \pm 1.2$ & $11 \pm 0.5$ & $\begin{array}{c}10 \\
\pm 0 \\
3\end{array}$ & 0.0 & $\begin{array}{c}16 \\
\pm 1.5\end{array}$ & $16 \pm 0.7$ & $\begin{array}{c}11 \\
\pm 1.4\end{array}$ & 0.0 & 0.0 & 0.0 & $14 \pm 0.6$ \\
\hline E. coli & 0.0 & 0.0 & 0.0 & 0.0 & 0.0 & $\begin{array}{c}20 \\
\pm 0.7\end{array}$ & $10 \pm 1.3$ & 0.0 & 0.0 & $14 \pm 0.5$ & 0.0 & 0.0 \\
\hline A. hydrophila & 0.0 & 0.0 & 0.0 & 0.0 & 0.0 & 0.0 & 0.0 & 0.0 & 0.0 & 0.0 & 0.0 & 0.0 \\
\hline V. damsela & 0.0 & 0.0 & 0.0 & 0.0 & 0.0 & 0.0 & 0.0 & 0.0 & 0.0 & 0.0 & 0.0 & 0.0 \\
\hline
\end{tabular}

$\mathrm{A}=$ acetone, $\mathrm{E}=$ ethanol, $\mathrm{EA}=$ ethyl acetate, and $\mathrm{M}=$ methanol.0; no activity (Resistant), 10 mm; moderate activity, $\sim 15 \mathrm{~mm}$; high activity, and $\sim 20 \mathrm{~mm}$ very high activity.

The results in the Table 3 exhibited that there were rather than low values in the antifungal activities from sponges extracts except against $P$. crustosum and A. terreus. 
Specifically, the suppression was in the range of $10-100 \%$ by all kinds of crude extracts. The ethanolic extract of $\underline{C}$. arabica and ethyl acetate extract of $\underline{C}$. penicillus had the highest suppression \%, followed by the ethanolic extract of $C$. penicillus as of $90 \%$. The lowest value of the suppression \% was for the ethanolic extract of C. penicillus $(10 \%)$. The other fungi were not suppressed at all, besides $C$. albicans.

Table 3: Antifungal activity of different sponge extracts against some fungal reference strains.

\begin{tabular}{|c|c|c|c|c|c|c|c|c|c|c|c|c|}
\hline \multirow{3}{*}{$\begin{array}{c}\text { Fungal } \\
\text { pathogen }\end{array}$} & \multicolumn{12}{|c|}{ Suppression $\%$ /species crude extract } \\
\hline & \multicolumn{4}{|c|}{ Long tree sponge } & \multicolumn{4}{|c|}{ Brown sponge } & \multicolumn{4}{|c|}{ Yellow sponge } \\
\hline & $\mathbf{E}$ & $\mathbf{E A}$ & $\mathbf{M}$ & $\mathbf{A}$ & $\mathbf{E}$ & $\mathbf{E A}$ & $\mathbf{M}$ & $\mathbf{A}$ & $\mathbf{E}$ & EA & $\mathbf{M}$ & $\bar{A}$ \\
\hline P. crustosum & $\begin{array}{c}40 \\
\pm 1.3\end{array}$ & $\begin{array}{c}80 \\
\pm 0.5\end{array}$ & $\begin{array}{c}70 \\
\pm 0.7\end{array}$ & $\begin{array}{c}50 \\
\pm 0.6\end{array}$ & $\begin{array}{c}100 \\
\pm 0.0\end{array}$ & $\begin{array}{c}70 \\
\pm 0.9\end{array}$ & $\begin{array}{c}50 \\
\pm 1.0\end{array}$ & $\begin{array}{c}60 \\
\pm 0.1\end{array}$ & $\begin{array}{c}90 \\
\pm 0.0\end{array}$ & $\begin{array}{c}100 \\
\pm 0.0\end{array}$ & $\begin{array}{c}60 \\
\pm 1.1\end{array}$ & $\begin{array}{c}50 \\
\pm 0.4\end{array}$ \\
\hline P. notatum & NS & NS & NS & NS & NS & NS & NS & NS & NS & NS & NS & NS \\
\hline A. niger & NS & NS & NS & NS & NS & NS & NS & NS & NS & NS & NS & NS \\
\hline F. solani & NS & NS & NS & NS & NS & NS & NS & NS & NS & NS & NS & NS \\
\hline A. terreus & $\begin{array}{c}50 \\
\pm 0.7\end{array}$ & NS & $\begin{array}{c}50 \\
\pm 1.0\end{array}$ & NS & NS & $\begin{array}{c}50 \\
\pm 0.5\end{array}$ & $\begin{array}{c}20 \\
\pm 0.7\end{array}$ & NS & $\begin{array}{c}20 \\
\pm 1.5\end{array}$ & $\begin{array}{c}10 \\
\pm 0.0\end{array}$ & NS & NS \\
\hline C. albicans ${ }^{* *}$ & 0.0 & 0.0 & 0.0 & 0.0 & 0.0 & 0.0 & 0.0 & 0.0 & 0.0 & 0.0 & 0.0 & 0.0 \\
\hline
\end{tabular}

"Suppression \% refers to the antifungal activity which was calculated according to the equation mentioned in methodology section. ${ }^{* *}$ Suppression $\%$ of $C$. albicans was calculated in mm like done for the antibacterial activity. NS means no suppression was detected. $\mathrm{A}=$ acetone, $\mathrm{E}=$ ethanol, $\mathrm{EA}=$ ethyl acetate, and $\mathrm{M}=$ methanol.

Furthermore, data in the Table 4 summarized the antimicrobial activities values from sea cucumber; $H$. atra extracts. The positive records of antibacterial activities ranged between 10 and $16 \mathrm{~mm}$. The highest activity was detected by methanolic crude extract against $A$. hydrophila, followed by the same extract against $S$. aureus $(14 \mathrm{~mm})$. Only $P$. notatum was the fungus that affected by both ethanolic and methanolic extracts with $20 \%$ suppression, while the other fungi were not influenced at all.

To sea cucumber, Mokhlesi et al. (2011) evaluated the antibacterial and antifungal activities of the ethyl acetate, methanol, and water-methanol extracts of the cuvierian organ, coelomic fluid, and body wall of the sea cucumber, Bohadschia marmorata, collected from Persian Gulf, against A. niger, C. albicans, S. aureus, $P$. aeruginosa, and E. coli. Their results showed that methanol extract of body wall and water-methanolic extract of cuvierian organ (against A. niger) and methanol extract of body wall and water-methanolic extract of cuvierian organ (against $C$. albicans) showed significant antifungal activities but no inhibitory effect of the extracts against bacteria was observed. Ibrahim (2012) assayed the antibacterial activities of flesh and coelomic fluids of three 
species of sea cucumber; Holothuria scabra, Holothuria leucospilota, and Holothuria atra, were detected against number of human and fish pathogens (S. aureus ATCC 6538, P. aeruginosa ATCC 8739, V. damsela, S. faecalis, and E. coli). However, considerable antibacterial activities were observed in the methanolic extracts of coelomic fluid and flesh of all Holothuria species against S. aureus ATCC 6538. Their AU ranged from 2.3 to 2.8. Noticeably, crude extracts of $H$. scabra exhibited abroad spectrum effect against all tested pathogens. Muthulakshmi et al. (2012) reported the biological activity due to the identified components in the methanolic extracts of $H$. scabra. They revealed that the phenolic nature of phenol, 4-(3-hydroxy-1-propenyl)-2-methoxy-compound, the steroid

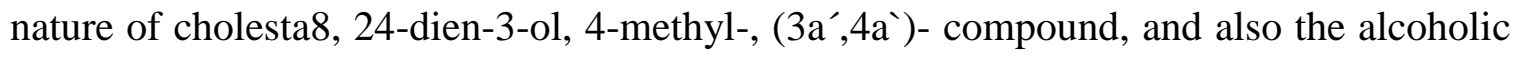
nature of 2-isopropyl-5methyl-1-heptanol compound showed potent antimicrobial activity. In recent findings, Dhinakaran and Lipton, (2014) observed that the methanol extracts of $H$. atra showed antimicrobial activity against $S$. aureus MTCC737, E. coli MTCC443, K. pneumonia MTCC109, Listeria monocytogenes MTCC1143, and Serratia liquefaciens MTCC3039.

Table 4: Antimicrobial activity of different extracts sea cucumber; $H$. atra on reference strains.

\begin{tabular}{|c|c|c|c|c|}
\hline \multirow[t]{2}{*}{ Pathogen } & \multicolumn{4}{|c|}{ Inhibition zone $(\mathrm{mm}) /$ solvent } \\
\hline & $\mathbf{E}$ & EA & $\mathbf{M}$ & $\mathbf{A}$ \\
\hline \multicolumn{5}{|l|}{ Bacteria: } \\
\hline E. coli & 0.0 & 0.0 & $12 \pm 0.0$ & 0.0 \\
\hline E. faecalis & 0.0 & 0.0 & 0.0 & 0.0 \\
\hline S. aureus & $10 \pm 0.3$ & 0.0 & $14 \pm 1.0$ & 0.0 \\
\hline P. aeruginosa & 0.0 & 0.0 & 0.0 & 0.0 \\
\hline B. subitilis & 0.0 & 0.0 & 0.0 & 0.0 \\
\hline A. hydrophila & $13 \pm 1.2$ & 0.0 & $16 \pm 0.9$ & 0.0 \\
\hline V. damsela & 0.0 & 0.0 & 0.0 & 0.0 \\
\hline S. epidermids & 0.0 & 0.0 & 0.0 & 0.0 \\
\hline Fungi: & \multicolumn{4}{|c|}{ Suppression \%/solvent } \\
\hline P. crustosum & NS & NS & NS & NS \\
\hline P. notatum & $20 \pm 0.7$ & NS & $20 \pm 0.5$ & NS \\
\hline A. terreus & NS & NS & NS & NS \\
\hline A. niger & NS & NS & NS & NS \\
\hline F. solani & NS & NS & NS & NS \\
\hline C. albicans ${ }^{*}$ & 0.0 & 0.0 & 0.0 & 0.0 \\
\hline
\end{tabular}

*Inhibition of $C$. albicans was calculated in $\mathrm{mm}$ like done for the antibacterial activity. NS means no suppression was detected 0 ; no activity (Resistant), $\sim 10 \mathrm{~mm}$; moderate activity, $\sim 15 \mathrm{~mm}$; high activity, and $\sim 20 \mathrm{~mm}$ very high activity. $\mathrm{A}=$ acetone, $\mathrm{E}=$ ethanol, $\mathrm{EA}=$ ethyl acetate, and $\mathrm{M}=$ methanol.

On comparison level, the activity of several commercial antibiotics (mm) was examined and then compared to the results of $A$. fasciata crude extract (mm) (Table 5). 
Basically, Gram positive showed obvious susceptibility towards most of the tested antibiotics. In fact, B. subtlis was sensitive towards Cephalexin, Rifampicin, and Piperacillin, while it was resistant towards both Metronidazole and Amikacin. Also, $B$. cerues, was sensitive towards Cephalexin, Rifampicin, and Amikacin, while it was resistant towards both Piperacillin and Metronidazole. As well as, S. aureus was sensitive toward both Cephalexin and Metronidazole, while it was resistant towards Rifampicin, Piperacillin, and Amikacin. On contrary, S. epidermids and E. faecalis exhibited clear resistance towards all tested antibiotics. Also, P. aeruginosa behaved like them except for Cephalexin and Metronidazole, where they showed intermediate sensitivity. In addition, E. coli was only susceptible against Cephalexin. By comparing the current crude extracts of sponges and sea cucumber to commercial antibiotics, it was observed that the good efficacy of these extracts. Even, they would need a strong purification process to be used in very low concentrations as commercial antibiotics.

Table 5: Effect of different commercial antibiotics on reference strains in comparing to $\underline{C}$. arabica crude extract.

\begin{tabular}{ccccccc}
\hline \multirow{2}{*}{$\begin{array}{c}\text { Reference } \\
\text { bacteria }\end{array}$} & $\begin{array}{c}\text { Inhibition } \\
\text { zone }(\mathbf{m m})^{*} \text { of } \\
\text { C. } \text {. } \begin{array}{c}\text { arabica } \\
\text { crude extract }\end{array}\end{array}$ & $\begin{array}{c}\text { Cephalexin } \\
(\mathbf{C L}, \mathbf{3 0} \boldsymbol{\mu g})\end{array}$ & $\begin{array}{c}\text { Rifampicin } \\
(\mathbf{R F}, \mathbf{3 0} \boldsymbol{\mu g})\end{array}$ & $\begin{array}{c}\text { Piperacillin } \\
(\mathbf{T Z P}, \mathbf{1 0} \boldsymbol{\mu g})\end{array}$ & $\begin{array}{c}\text { Metronidazole } \\
(\mathbf{M T Z , ~ 2 0} \boldsymbol{\mu g})\end{array}$ & $\begin{array}{c}\text { Amikacin } \\
(\mathbf{A M K}, \mathbf{3 0} \boldsymbol{\mu g})\end{array}$ \\
\hline B. subtlis & 14 & 23 & 21 & 13 & 7 & 0 \\
B. cerues & 0 & 25 & 14 & 6 & 0 & 22 \\
S. aureus & 0 & 30 & 9 & 9 & 29 & 8 \\
S. epidermids & 0 & 10 & 0 & 0 & 9 & 0 \\
E. faecalis & 14 & 6 & 6 & 6 & 6 & 0 \\
P. aeruginosa & 16 & 0 & 0 & 0 & 12 & 0 \\
E. coli & 20 & 23 & 0 & 0 & 0 & 0 \\
\hline
\end{tabular}

"These values taken were representative as the highest average from Table 2. 0; no activity (Resistant), 10 mm; moderate activity, $\sim 15 \mathrm{~mm}$; high activity, and $\sim 20 \mathrm{~mm}$ very high activity.

On the other hand, the results of GC-MS/MS of ethanol-extract from C. arabica revealed the presence of several bioactive constituents, with 11 major compounds (Fig. 2 $\&$ Table 6). The chemical profiles of them are mainly: Dimethyl sulfone $(41.86 \%)$, Pyridine, 2-nitro (16.30\%), 1,3,2-Dioxathiolane, 2-oxide (20.90\%), S-Methyl methanethiosulphonate (88.59\%), 1,2,4-Trithiolane (46.63\%), 4,25-Secoobscurinervan-4one, O-acetyl-22-ethyl-15,16-dimethoxy-, (22à) (24.07\%), Methyl N-(Nbenzyloxycarbonyl-beta-l-aspartyl)-beta-d-glucosaminide $\quad(6.70 \%), \quad 2-A m i n o-3-(4-$ hydroxyphenyl)- propanoic acid (9.29\%), Cyclohexasiloxane, dodecamethyl (86.47\%), 2,7-Diphenyl-1,6-Dioxopyridazino [4,5:2',3'] Pyrrolo [4',5'-d]pyridazine (17.24\%), and Cycloheptasiloxane, tetradecamethyl $(77.56 \%)$. Also, the GC-MS/MS results of $\underline{C}$. arabica ethyl acetate-extract revealed the presence of several bioactive constituents, with 12 major compounds (Fig. $2 \&$ Table 6). The chemical profiles of them are mainly: undefined (59.72\%), Pyridinium, 1-amino-, hydroxide, inner salt (62.20\%), Methanol, (1,4-dihydrophenyl) (11.36\%), Bicyclo[3.3.1]non-6-ene-3-carboxylic acid (8.16\%), S- 
Methyl methanethiosulphonate $(64.00 \%), 4,25$-Secoobscurinervan-4-one, O-acetyl-22ethyl-15,16-dimethoxy-, (22à) (10.18\%), Pyridine, 2-nitro (9.18\%), 1,2,4-Trithiolane (76.56\%), 3-Nitropyridine 1-oxide (7.42\%), Carbonotrithioic acid, dimethyl ester (42.05\%), 2,5-Anhydro-1-deoxy-1-(2-pyridylamino)-d-mannitol (15.53\%), and Cyclohexasiloxane, dodecamethy (93.10\%).

In addition, the results of GC-MS/MS of ethanol-extract from $\underline{C}$. arabica revealed the presence of several bioactive constituents, with 4 major compounds (Fig. 2 \& Table 6). The chemical profiles of them are mainly: Pyridinium, 1-amino-, hydroxide, inner salt (40.23\%), Pentasiloxane, 1,1,3,3,5,5,7,7,9,9-decamethyl (14.68\%), Carbonotrithioic acid, dimethyl ester (73.11\%), and Cyclohexasiloxane, dodecamethyl (93.79\%). Moreover, the results of GC-MS/MS of methanol-extract from $\underline{C}$. arabica revealed the presence of several bioactive constituents, with 8 major compounds (Fig. 2 \& Table 6). The chemical profiles of them are mainly: S-Methyl methanethiosulphonate $(78.37 \%), 1,2,4$-Trithiolane (40.93\%), 2,5-Anhydro-1-deoxy-1-(2-pyridylamino)-d-mannitol $(14.22 \%)$, Bicyclo[2.2.1]hept-5-ene-2-carboxylic acid (8.90\%), 2,5-Anhydro-1-deoxy-1-(2pyridylamino)-d-mannitol (12.59\%), Cycloheptasiloxane, tetradecamethyl (76.95\%), Benzofuran, 7-(2,4-dinitrophenoxy)-2,3-dihydro-2,2-dimethyl (9.98\%), and Cyclooctasiloxane, hexadecamethyl (36.65\%).

Likewise, the results of GC-MS/MS of ethanol-extract from $H$. atra revealed the presence of several bioactive constituents, with 18 major compounds (Fig. 3 \& Table 7). The chemical profiles of them are mainly: Pyridinium, 1-amino-, hydroxide, inner salt (58.68\%), Ethanol, 2-mercapto (57.99\%), 1,3,2-Dioxathiolane, 2-oxide (50.15\%), SMethyl methanethiosulphonate (79.92\%), 3,7,7-Trimethyl-8-(2-methyl-propenyl)bicyclo[4.2.0] oct-2-ene (21.13), 1,2,4-Trithiolane (90.07\%), 3-Nitropyridine 1-oxide (19.61\%), Spirost-8-en-11-one, 3-hydroxy-, (3á,5à,14á,20á,22á,25R) (6.38\%), Bicyclo[2.2.1]hept-5-ene-2-carboxylic acid (8.33\%), Bicyclo[2.2.1]hept-5-ene-2carboxylic acid (9.32\%), 4,25-Secoobscurinervan-4-one, O-acetyl-22-ethyl-15,16dimethoxy-, (22à) (19.62\%), Cyclohexasiloxane, dodecamethyl (94.87), Malonodinitrile, 2-[1-cyclopropyl-3-(4-nitrophenyl)prop-2-enylideno] (9.20), 2,7-Diphenyl-1,6dioxopyridazino[4,5:2',3']pyrrolo[4',5'-d]pyridazine (13.71), Ethyl iso-allocholate (24.82), Cycloheptasiloxane, tetradecamethyl (81.32), 2-Cyclopropene-1-carboxylic acid, 2-(1,1dimethyl-5-oxohexyl)-, methyl ester (10.09), and Cyclooctasiloxane, hexadecamethyl (64.99). Additionally, the results of GC-MS/MS of methanol-extract from $H$. atra revealed the presence of several bioactive constituents, with 15 major compounds (Fig. 3 $\&$ Table 7). The chemical profiles of them are mainly: Methanesulfonylacetic acid (34.70\%), 2,3-Dihydro-6-hydroxy-3-oxo-2-(piperidinomethyl)pyridazine (39.23\%), Acetic acid butyl-methyl-phosphinoylmethyl ester (14.13\%), S-Methyl methanethiosulphonate $(85.34 \%), 1,2,4$-Trithiolane $(62.85 \%), \quad 2$-[4-methyl-6- $(2,6,6-$ trimethylcyclohex-1-enyl)hexa-1,3,5-trienyl]cyclohex-1-en-1-carboxaldehyde $\quad(5.83 \%)$, 4,25-Secoobscurinervan-4-one, O-acetyl-22-ethyl-15,16-dimethoxy-, (22à) (29.54\%), 
N,N'-Bis(Carbobenzyloxy)-lysine methyl(ester) (23.68\%), 2-Propen-1-ol, 2-methyl-3(2,6,6-trimethyl-2-cyclohexen-1-yl)-,

(E) $\quad(8.49 \%), \quad 2-A m i n o-3-(4-h y d r o x y p h e n y l)-$ propanoic acid (7.64\%), Cyclohexasiloxane, dodecamethyl (91.46\%), Z,Z,Z-4,6,9Nonadecatriene (6.81\%), Cycloheptasiloxane, tetradecamethyl (72.91\%), Cyclooctasiloxane, hexadecamethyl (43.78\%), and Ergosta-5,22-dien-3-ol, acetate, (3á,22E) $(6.81 \%)$.
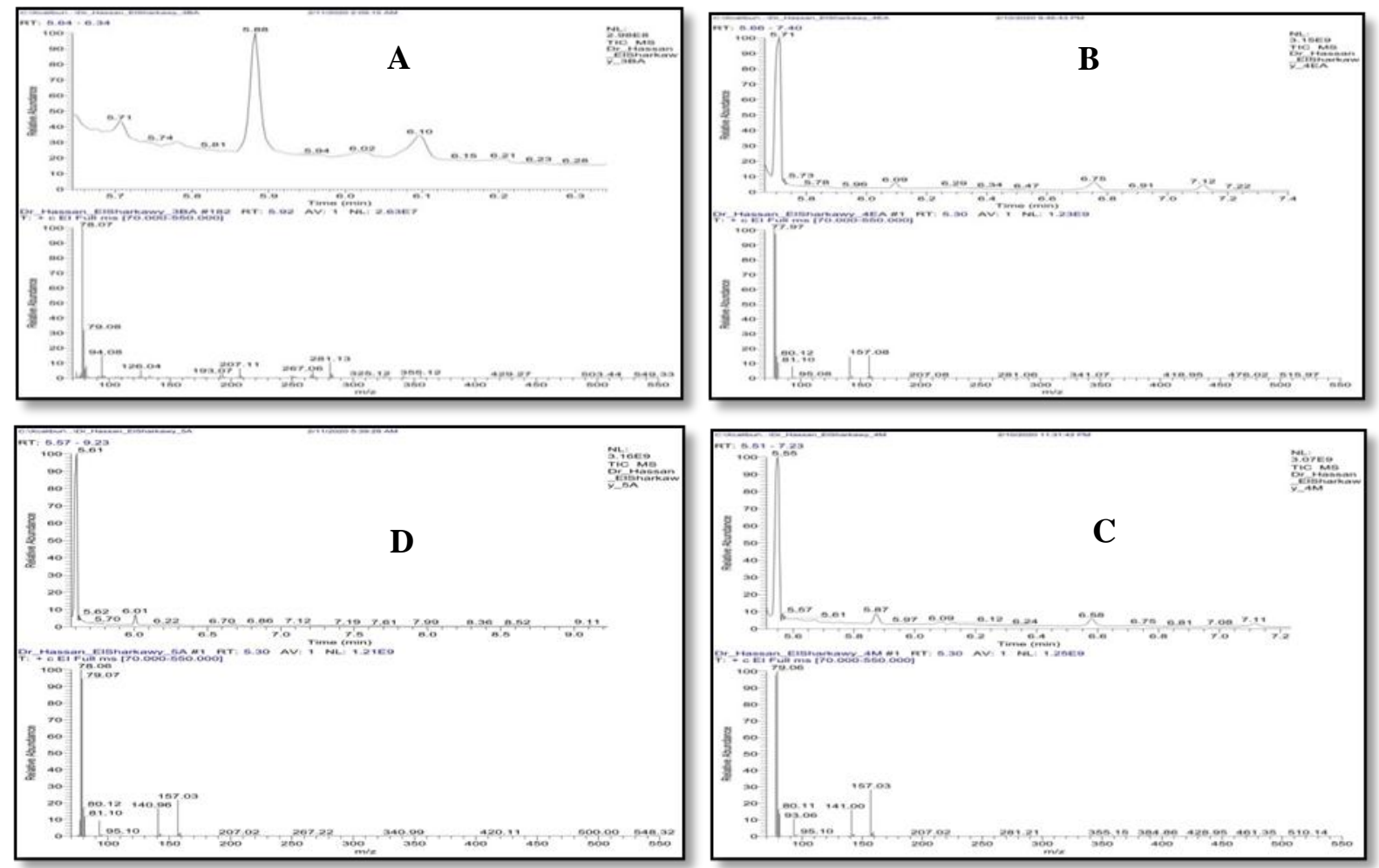

Fig. 2: GC-MS/MS chromatogram of different $\underline{C}$. arabica crude extracts; ethanolic (A), methanolic (C), and acetone (D) showing the retention time and molecular weights of the identified compounds.
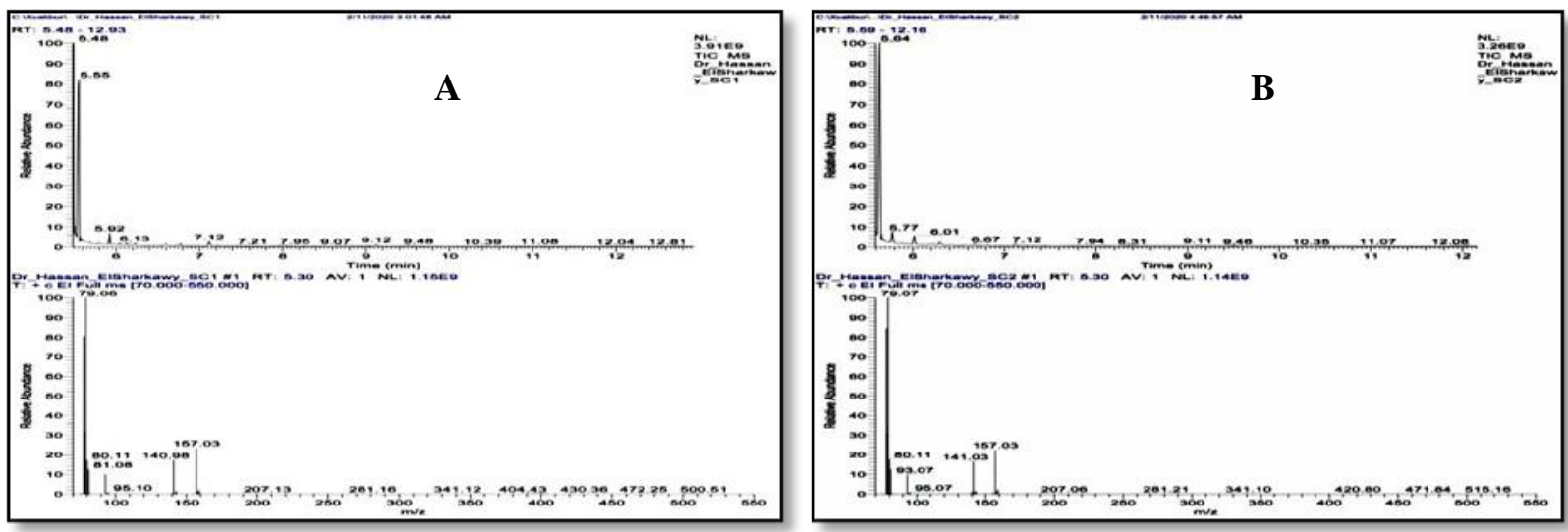

Fig. 3: GC-MS/MS chromatogram of $H$. atra ethanolic extract (A) and methanolic extract (B) showing the retention time and molecular weights of the identified compounds. 
On the other side, the potential compounds with bioactivity detected by GC-MS in the our crude extracts were organic and fatty acids and their derivatives, besides much other of organic alcohols, steroids, terpenoids, amino acids, esters and benzene derivatives. However, the most of these constituents have been proven as antibacterial and antifungal agents (Ibrahim, 2012; Moustafa et al., 2013; Hussein et al., 2016; Ibrahim et al., 2018).

Indeed, several workers have discussed the effectiveness of the constituents that were obtained in the present crude extracts. For instance, Matsunaga et al. (1989) isolated an antifungal and cytotoxic cyclic tetrapeptide from a Theonella sponge and halicylindramides from the marine sponge Halichondria cylindrata. Ryu et al. (1994) concluded that the methanolic extract of marine sponge exhibited significant antifungal activity and antibacterial activity to both Gram-positive and Gram-negative bacteria. Also, Clark et al. (1998) isolated a cyclicdipsipeptide, cyclolithistide from a marine sponge; Theonella swinhoei (Gray, 1868), and this molecule exhibited significant antifungal activity against $C$. albicans but not against $E$. coli or B. subtilis. As well as, Otero-González et al. (2010) observed that a promising novel use of antimicrobial peptides from the marine sponge Discodermia kiiensis, could be a potent drug in both human and veterinary medicine based upon their potential characteristics.

Recently, Ibrahim et al. (2018) detected the principal components in the sponge C. penicillus extracts by GC-MS as fatty acids and their esters (hexadecanoic acid and octadecanoic acid), as well as, steroids and terpenoids, which have antimicrobial effects. Fatty acids are able to act as anionic surfactants; they also possess antifungal and antibacterial characteristics at low pH (AbouElela et al., 2009; Ibrahim and Abd El-Naby, 2010). More specifically, diterpene isonitriles isolated from the tropical marine sponge Cymbastela hooperi, and the sesquiterpene axisonitrile-3, isolated from the tropical marine sponge Acanthella kletra, were evaluated as anti-fouling, anti-algal, antiphotosynthetic, antibacterial, antifungal, and anti-tubercular agents (Wright et al., 2011). Also, Halogenated alkaloids named purpuroines A-J were isolated from the marine sponge Lotrochota purpurea. Tests of these compounds showed inhibitory activity against diseases related to fungi and bacteria (Shen et al., 2012). Shen et al. (2012) isolated novel cyclic bis-1,3-dialkylpyridiniums and cyclostellettamines from the sponge Haliclona sp. in Korea. As well as, Yang et al. (2012) isolated new alkaloids, (-)-8'-oxoagelasine $\mathrm{D}$, ageloxime $\mathrm{B},(+)$-2-oxo-agela-sidine $\mathrm{C}$, 4-bromo- $\mathrm{N}$-(butoxymethyl)1Hpyrrole-2-carboxamide and (-)-ageloxime D from the marine sponge Agelas mauritiana. Some of these metabolites showed antifungal activity against Cryptococcus neoformans, antileishmanial activity in vitro and antibacterial activity against Staphylococcus aureus and methicillin-resistant S. aureus. 
Table 6: Chemical constituents detected in different extracts of $C$. arabica by GC-MS/MS.

\begin{tabular}{|c|c|c|c|c|c|c|c|c|}
\hline $\begin{array}{c}\text { Peak } \\
\text { No. }\end{array}$ & Compound name & $\begin{array}{c}\text { RT } \\
(\mathbf{m i n})\end{array}$ & $\begin{array}{l}\text { Molecular } \\
\text { formula }\end{array}$ & $\begin{array}{l}\text { MW } \\
(\mathbf{m} / \mathbf{z})\end{array}$ & Hit & SI & RSI & $\begin{array}{c}\text { Prob. } \\
(\%)\end{array}$ \\
\hline \multicolumn{9}{|c|}{ C. arabica acetone extract: } \\
\hline 1 & Dimethyl sulfone & 5.60 & $\mathrm{C}_{2} \mathrm{H}_{6} \mathrm{O}_{2} \mathrm{~S}$ & 94 & 1 & 874 & 863 & 41.86 \\
\hline 2 & Pyridine, 2-nitro & 5.75 & $\mathrm{C}_{5} \mathrm{H}_{4} \mathrm{~N}_{2} \mathrm{O}_{2}$ & 124 & 1 & 577 & 735 & 16.30 \\
\hline 3 & 1,3,2-Dioxathiolane, 2-oxide & 5.87 & $\mathrm{C}_{2} \mathrm{H}_{4} \mathrm{O}_{3} \mathrm{~S}$ & 108 & 1 & 578 & 861 & 20.90 \\
\hline 4 & S-Methyl methanethiosulphonate & 6.10 & $\mathrm{C}_{2} \mathrm{H}_{6} \mathrm{O}_{2} \mathrm{~S}_{2}$ & 126 & 1 & 743 & 838 & 88.59 \\
\hline 5 & 1,2,4-Trithiolane & 6.22 & $\mathrm{C}_{2} \mathrm{H}_{4} \mathrm{~S}_{3}$ & 124 & 1 & 590 & 875 & 46.63 \\
\hline 6 & $\begin{array}{l}\text { 4,25-Secoobscurinervan-4-one, O-acetyl-22-ethyl- } \\
\text { 15,16-dimethoxy-, (22à) }\end{array}$ & 6.30 & $\mathrm{C}_{27} \mathrm{H}_{36} \mathrm{~N}_{2} \mathrm{O}_{6}$ & 484 & 1 & 580 & 583 & 24.07 \\
\hline 7 & $\begin{array}{l}\text { Methyl N-(N-benzyloxycarbonyl-beta-l-aspartyl)- } \\
\text { beta-d-glucosaminide }\end{array}$ & 6.70 & $\mathrm{C}_{19} \mathrm{H}_{26} \mathrm{~N}_{2} \mathrm{O}_{10}$ & 442 & 1 & 532 & 574 & 6.70 \\
\hline 8 & 2-Amino-3-(4-hydroxyphenyl)-propanoic acid & 6.86 & $\mathrm{C}_{9} \mathrm{H}_{11} \mathrm{NO}_{3}$ & 181 & 1 & 616 & 714 & 9.29 \\
\hline 9 & Cyclohexasiloxane, dodecamethyl & 7.12 & $\mathrm{C}_{12} \mathrm{H}_{36} \mathrm{O}_{6} \mathrm{Si}_{6}$ & 444 & 1 & 745 & 811 & 86.47 \\
\hline 10 & $\begin{array}{l}\text { 2,7-Diphenyl-1,6- } \\
\text { dioxopyridazino[4,5:2',3']pyrrolo[4',5'-d]pyridazine }\end{array}$ & 7.90 & $\mathrm{C}_{20} \mathrm{H}_{13} \mathrm{~N}_{5} \mathrm{O}_{2}$ & 355 & 1 & 568 & 599 & 17.24 \\
\hline 11 & Cycloheptasiloxane, tetradecamethyl & 9.11 & $\mathrm{C}_{14} \mathrm{H}_{42} \mathrm{O}_{7} \mathrm{Si}_{7}$ & 518 & 1 & 732 & 834 & 77.56 \\
\hline \multicolumn{9}{|c|}{ C. arabica methanol extract: } \\
\hline 1 & Undefined $\left\{\left(\mathrm{CH}_{3}\right)_{2} \mathrm{NCl}\right\}$ & 5.56 & $\mathrm{C}_{2} \mathrm{H}_{6} \mathrm{ClN}$ & 79 & 1 & 617 & 859 & 59.72 \\
\hline 2 & Pyridinium, 1-amino-, hydroxide, inner salt & 5.57 & $\mathrm{C}_{5} \mathrm{H}_{6} \mathrm{~N}_{2}$ & 94 & 1 & 854 & 918 & 62.20 \\
\hline 3 & Methanol, (1,4-dihydrophenyl) & 5.61 & $\mathrm{C}_{7} \mathrm{H}_{10} \mathrm{O}$ & 110 & 1 & 535 & 671 & 11.36 \\
\hline 4 & Bicyclo[3.3.1]non-6-ene-3-carboxylic acid & 5.75 & $\mathrm{C}_{10} \mathrm{H}_{14} \mathrm{O}_{2}$ & 166 & 2 & 521 & 641 & 8.16 \\
\hline 5 & S-Methyl methanethiosulphonate & 5.87 & $\mathrm{C}_{2} \mathrm{H}_{6} \mathrm{O}_{2} \mathrm{~S}_{2}$ & 126 & 1 & 604 & 777 & 64.00 \\
\hline 6 & $\begin{array}{l}\text { 4,25-Secoobscurinervan-4-one, O-acetyl-22-ethyl- } \\
\text { 15,16-dimethoxy-, (22à) }\end{array}$ & 5.97 & $\mathrm{C}_{27} \mathrm{H}_{36} \mathrm{~N}_{2} \mathrm{O}_{6}$ & 484 & 1 & 519 & 522 & 10.18 \\
\hline 7 & Pyridine, 2-nitro & 6.05 & $\mathrm{C}_{5} \mathrm{H}_{4} \mathrm{~N}_{2} \mathrm{O}_{2}$ & 124 & 1 & 519 & 742 & 9.18 \\
\hline 8 & 1,2,4-Trithiolane & 6.09 & $\mathrm{C}_{2} \mathrm{H}_{4} \mathrm{~S}_{3}$ & 124 & 1 & 638 & 861 & 76.56 \\
\hline 9 & 3-Nitropyridine 1-oxide & 6.12 & $\mathrm{C}_{5} \mathrm{H}_{4} \mathrm{~N}_{2} \mathrm{O}_{3}$ & 140 & 1 & 517 & 639 & 7.42 \\
\hline 10 & Carbonotrithioic acid, dimethy & 6.58 & $\mathrm{C}_{3} \mathrm{H}_{6} \mathrm{~S}_{3}$ & 138 & 1 & 634 & 765 & 42.05 \\
\hline 11 & $\begin{array}{l}\text { 2,5-Anhydro-1-deoxy-1-(2-pyridylamino)-d- } \\
\text { mannitol }\end{array}$ & 6.75 & $\mathrm{C}_{11} \mathrm{H}_{16} \mathrm{~N}_{2} \mathrm{O}_{4}$ & 240 & 1 & 565 & 764 & 15.53 \\
\hline 12 & Cyclohexasiloxane, dodecamethy & 7.11 & $\mathrm{C}_{12} \mathrm{H}_{36} \mathrm{O}_{6} \mathrm{Si}_{6}$ & 444 & 1 & 768 & 840 & 93.10 \\
\hline \multicolumn{9}{|c|}{ C. arabica ethyl acetate extract: } \\
\hline 1 & Pyridinium, 1-amino-, hydroxide, inner salt & 5.71 & $\mathrm{C}_{5} \mathrm{H}_{6} \mathrm{~N}_{2}$ & 94 & 3 & 839 & 906 & 40.23 \\
\hline 2 & Pentasiloxane, 1,1,3,3,5,5,7,7,9,9-decamethyl & 6.09 & $\mathrm{C}_{10} \mathrm{H}_{32} \mathrm{O}_{4} \mathrm{Si}_{5}$ & 356 & 1 & 532 & 647 & 14.68 \\
\hline 3 & Carbonotrithioic acid, dimethyl ester & 6.75 & $\mathrm{C}_{3} \mathrm{H}_{6} \mathrm{~S}_{3}$ & 138 & 1 & 679 & 843 & 73.11 \\
\hline 4 & Cyclohexasiloxane, dodecamethyl & 7.12 & $\mathrm{C}_{12} \mathrm{H}_{36} \mathrm{O}_{6} \mathrm{Si}_{6}$ & 444 & 1 & 823 & 852 & 93.79 \\
\hline \multicolumn{9}{|c|}{ C. arabica ethanol extract: } \\
\hline 1 & S-Methyl methanethiosulphonate & 5.88 & $\mathrm{C}_{2} \mathrm{H}_{6} \mathrm{O}_{2} \mathrm{~S}_{2}$ & 126 & 1 & 637 & 818 & 78.37 \\
\hline 2 & 1,2,4-Trithiolane & 6.10 & $\mathrm{C}_{2} \mathrm{H}_{4} \mathrm{~S}_{3}$ & 124 & 1 & 572 & 861 & 40.93 \\
\hline 3 & $\begin{array}{l}\text { 2,5-Anhydro-1-deoxy-1-(2-pyridylamino)-d- } \\
\text { mannitol }\end{array}$ & 6.48 & $\mathrm{C}_{11} \mathrm{H}_{16} \mathrm{~N}_{2} \mathrm{O}_{4}$ & 240 & 1 & 579 & 747 & 14.22 \\
\hline 4 & Bicyclo[2.2.1]hept-5-ene-2-carboxylic acid & 6.60 & $\mathrm{C}_{8} \mathrm{H}_{10} \mathrm{O}_{2}$ & 138 & 1 & 532 & 720 & 8.90 \\
\hline 5 & $\begin{array}{l}\text { 2,5-Anhydro-1-deoxy-1-(2-pyridylamino)-d- } \\
\text { mannitol }\end{array}$ & 6.77 & $\mathrm{C}_{11} \mathrm{H}_{16} \mathrm{~N}_{2} \mathrm{O}_{4}$ & 240 & 1 & 548 & 746 & 12.59 \\
\hline 6 & Cycloheptasiloxane, tetradecamethyl & 9.12 & $\mathrm{C}_{14} \mathrm{H}_{42} \mathrm{O}_{7} \mathrm{Si}_{7}$ & 518 & 1 & 749 & 853 & 76.95 \\
\hline 7 & $\begin{array}{l}\text { Benzofuran, 7-(2,4-dinitrophenoxy)-2,3-dihydro- } \\
\text { 2,2-dimethyl }\end{array}$ & 9.48 & $\mathrm{C}_{16} \mathrm{H}_{1} 4 \mathrm{~N}_{2} \mathrm{O}_{6}$ & 330 & 1 & 531 & 582 & 9.98 \\
\hline 8 & Cyclooctasiloxane, hexadecamethyl & 11.80 & $\mathrm{C}_{16} \mathrm{H}_{48} \mathrm{O}_{8} \mathrm{Si}_{8}$ & 592 & 1 & 663 & 811 & 36.65 \\
\hline
\end{tabular}


Table 7: Chemical constituents detected in different extracts of $H$. atra by GC-MS/MS.

\begin{tabular}{|c|c|c|c|c|c|c|c|c|}
\hline $\begin{array}{c}\text { Peak } \\
\text { No. }\end{array}$ & Compound name & $\begin{array}{c}\text { RT } \\
(\mathbf{m i n})\end{array}$ & $\begin{array}{c}\text { Molecular } \\
\text { formula }\end{array}$ & $\begin{array}{l}\text { MW } \\
(\mathbf{m} / \mathbf{z})\end{array}$ & Hit & SI & RSI & $\begin{array}{c}\text { Prob. } \\
(\%)\end{array}$ \\
\hline \multicolumn{9}{|c|}{ H. atra ethanol extract: } \\
\hline 1 & Pyridinium, 1-amino-, hydroxide, inner salt & 5.55 & $\mathrm{C}_{5} \mathrm{H}_{6} \mathrm{~N}_{2}$ & 94 & 1 & 847 & 902 & 58.68 \\
\hline 2 & Ethanol, 2-mercapto & 5.69 & $\mathrm{C}_{2} \mathrm{H}_{6} \mathrm{OS}$ & 78 & 1 & 611 & 894 & 57.99 \\
\hline 3 & 1,3,2-Dioxathiolane, 2-oxide & 5.79 & $\mathrm{C}_{2} \mathrm{H}_{4} \mathrm{O}_{3} \mathrm{~S}$ & 108 & 1 & 604 & 888 & 50.15 \\
\hline 4 & S-Methyl methanethiosulphonate & 5.92 & $\mathrm{C}_{2} \mathrm{H}_{6} \mathrm{O}_{2} \mathrm{~S}_{2}$ & 126 & 1 & 649 & 802 & 79.92 \\
\hline 5 & $\begin{array}{l}\text { 3,7,7-Trimethyl-8-(2-methyl-propenyl)- } \\
\text { bicyclo[4.2.0]oct-2-ene }\end{array}$ & 6.04 & $\mathrm{C}_{15} \mathrm{H}_{24}$ & 204 & 1 & 564 & 666 & 21.13 \\
\hline 6 & 1,2,4-Trithiolane & 6.13 & $\mathrm{C}_{2} \mathrm{H}_{4} \mathrm{~S}_{3}$ & 124 & 1 & 741 & 923 & 90.07 \\
\hline 7 & 3-Nitropyridine 1-oxide & 6.23 & $\mathrm{C}_{5} \mathrm{H}_{4} \mathrm{~N}_{2} \mathrm{O}_{3}$ & 140 & 1 & 556 & 671 & 19.61 \\
\hline 8 & $\begin{array}{l}\text { Spirost-8-en-11-one, 3-hydroxy-, } \\
\text { (3á,5à,14á,20á,22á,25R) }\end{array}$ & 6.49 & $\mathrm{C}_{27} \mathrm{H}_{40} \mathrm{O}_{4}$ & 428 & 2 & 521 & 528 & 6.38 \\
\hline 9 & Bicyclo[2.2.1]hept-5-ene-2-carboxylic acid & 6.60 & $\mathrm{C}_{8} \mathrm{H}_{10} \mathrm{O}_{2}$ & 138 & 4 & 544 & 725 & 8.33 \\
\hline 10 & Benzamide, $\mathrm{N}$-(2-aminophenyl)-2,4,6-trinitro & 6.74 & $\mathrm{C}_{13} \mathrm{H}_{9} \mathrm{~N}_{5} \mathrm{O}_{7}$ & 347 & 1 & 578 & 656 & 9.32 \\
\hline 11 & $\begin{array}{l}\text { 4,25-Secoobscurinervan-4-one, O-acetyl-22-ethyl- } \\
\text { 15,16-dimethoxy-, (22à) }\end{array}$ & 6.98 & $\mathrm{C}_{27} \mathrm{H}_{36} \mathrm{~N}_{2} \mathrm{O}_{6}$ & 484 & 1 & 575 & 587 & 19.62 \\
\hline 12 & Cyclohexasiloxane, dodecamethyl & 7.12 & $\mathrm{C}_{12} \mathrm{H}_{36} \mathrm{O}_{6} \mathrm{Si}_{6}$ & 444 & 1 & 772 & 847 & 94.87 \\
\hline 13 & $\begin{array}{l}\text { Malonodinitrile, 2-[1-cyclopropyl-3-(4- } \\
\text { nitrophenyl)prop-2-enylideno] }\end{array}$ & 7.21 & $\mathrm{C}_{15} \mathrm{H}_{11} \mathrm{~N}_{3} \mathrm{O}_{2}$ & 265 & 1 & 534 & 634 & 9.20 \\
\hline 14 & $\begin{array}{l}\text { 2,7-Diphenyl-1,6- } \\
\text { dioxopyridazino[4,5:2',3']pyrrolo[4',5'-d]pyridazine }\end{array}$ & 7.95 & $\mathrm{C}_{20} \mathrm{H}_{13} \mathrm{~N}_{5} \mathrm{O}_{2}$ & 355 & 1 & 539 & 571 & 13.71 \\
\hline 15 & Ethyl iso-allocholate & 8.04 & $\mathrm{C}_{26} \mathrm{H}_{44} \mathrm{O}_{5}$ & 436 & 1 & 582 & 588 & 24.82 \\
\hline 16 & Cycloheptasiloxane, tetradecamethyl & 8.12 & $\mathrm{C}_{14} \mathrm{H}_{42} \mathrm{O}_{7} \mathrm{Si}_{7}$ & 518 & 1 & 757 & 858 & 81.32 \\
\hline 17 & $\begin{array}{l}\text { 2-Cyclopropene-1-carboxylic acid, 2-(1,1- } \\
\text { dimethyl-5-oxohexyl)-, methyl ester }\end{array}$ & 9.48 & $\mathrm{C}_{13} \mathrm{H}_{20} \mathrm{O}_{3}$ & 224 & 1 & 547 & 635 & 10.09 \\
\hline 18 & Cyclooctasiloxane, hexadecamethyl & 11.08 & $\mathrm{C}_{16} \mathrm{H}_{48} \mathrm{O}_{8} \mathrm{Si}_{8}$ & 592 & 1 & 700 & 806 & 64.99 \\
\hline \multicolumn{9}{|c|}{ H. atra methanol extract: } \\
\hline 1 & Methanesulfonylacetic acid & 5.62 & $\mathrm{C}_{3} \mathrm{H}_{6} \mathrm{O}_{4} \mathrm{~S}$ & 138 & 1 & 857 & 869 & 34.70 \\
\hline 2 & $\begin{array}{l}\text { 2,3-Dihydro-6-hydroxy-3-oxo-2- } \\
\text { (piperidinomethyl)pyridazine }\end{array}$ & 5.77 & $\mathrm{C}_{10} \mathrm{H}_{15} \mathrm{~N}_{3} \mathrm{O}_{2}$ & 209 & 1 & 622 & 646 & 39.23 \\
\hline 3 & Acetic acid butyl-methyl-phosphinoylmethyl ester & 5.88 & $\mathrm{C}_{8} \mathrm{H}_{17} \mathrm{O}_{3} \mathrm{P}$ & 192 & 1 & 583 & 722 & 14.13 \\
\hline 4 & S-Methyl methanethiosulphonate & 6.01 & $\mathrm{C}_{2} \mathrm{H}_{6} \mathrm{O}_{2} \mathrm{~S}_{2}$ & 126 & 1 & 705 & 811 & 85.34 \\
\hline 5 & 1,2,4-Trithiolane & 6.21 & $\mathrm{C}_{2} \mathrm{H}_{4} \mathrm{~S}_{3}$ & 124 & 1 & 648 & 910 & 62.85 \\
\hline 6 & $\begin{array}{l}\text { 2-[4-methyl-6-(2,6,6-trimethylcyclohex-1- } \\
\text { enyl)hexa-1,3,5-trienyl]cyclohex-1-en-1- } \\
\text { carboxaldehyde }\end{array}$ & 6.29 & $\mathrm{C}_{23} \mathrm{H}_{32} \mathrm{O}$ & 324 & 1 & 586 & 591 & 5.83 \\
\hline 7 & $\begin{array}{l}\text { 4,25-Secoobscurinervan-4-one, O-acetyl-22-ethyl- } \\
\text { 15,16-dimethoxy-, (22à) }\end{array}$ & 6.43 & $\mathrm{C}_{27} \mathrm{H}_{36} \mathrm{~N}_{2} \mathrm{O}_{6}$ & 484 & 1 & 587 & 602 & 29.54 \\
\hline 8 & N,N'-Bis(Carbobenzyloxy)-lysine methyl(ester) & 6.58 & $\mathrm{C}_{23} \mathrm{H}_{28} \mathrm{~N}_{2} \mathrm{O}_{6}$ & 428 & 1 & 581 & 621 & 23.68 \\
\hline 9 & $\begin{array}{l}\text { 2-Propen-1-ol, 2-methyl-3-(2,6,6-trimethyl-2- } \\
\text { cyclohexen-1-yl)-, (E) }\end{array}$ & 6.67 & $\mathrm{C}_{13} \mathrm{H}_{22} \mathrm{O}$ & 194 & 1 & 558 & 617 & 8.49 \\
\hline 10 & 2-Amino-3-(4-hydroxyphenyl)-propanoic acid & 6.82 & $\mathrm{C}_{9} \mathrm{H}_{11} \mathrm{NO}_{3}$ & 181 & 1 & 587 & 701 & 7.64 \\
\hline 11 & Cyclohexasiloxane, dodecamethyl & 7.12 & $\mathrm{C}_{12} \mathrm{H}_{36} \mathrm{O}_{6} \mathrm{Si}_{6}$ & 444 & 1 & 761 & 829 & 91.46 \\
\hline 12 & Z,Z,Z-4,6,9-Nonadecatriene & 7.93 & $\mathrm{C}_{19} \mathrm{H}_{34}$ & 262 & 1 & 566 & 639 & 6.81 \\
\hline 13 & Cycloheptasiloxane, tetradecamethyl & 9.11 & $\mathrm{C}_{14} \mathrm{H}_{42} \mathrm{O}_{7} \mathrm{Si}_{7}$ & 518 & 1 & 709 & 830 & 72.91 \\
\hline 14 & Cyclooctasiloxane, hexadecamethyl & 11.07 & $\mathrm{C}_{16} \mathrm{H}_{48} \mathrm{O}_{8} \mathrm{Si}_{8}$ & 592 & 1 & 659 & 794 & 43.78 \\
\hline 15 & Ergosta-5,22-dien-3-ol, acetate, (3á,22E) & 12.08 & $\mathrm{C}_{30} \mathrm{H}_{48} \mathrm{O}_{2}$ & 440 & 1 & 548 & 633 & 6.81 \\
\hline
\end{tabular}


Likewise, It has been established that there is a variety of antimicrobial compounds have been isolated from enchinoderms including steroidal glycosides (Jawahar et al., 2002), polyhydroxylated sterols (Iorizzi et al., 2001), peptides antibiotics (Beauregard et al., 2001), and complement-like substances (Leonard et al., 1990). Zou et al. (2005) isolated Intercedenside D-I as cytotoxic triterpene glycoside from the sea cucumber; Mensamaria intercedens, and $\mathrm{Wu}$ et al. (2006) extracted Hillaside C a triterpene derived from sea cucumber Holothuria hilla. In addition, Fuscocineroside C compound as a triterpene glycoside was obtained from sea cucumber Holothuria fuscocinerea that showed cytotoxic nature against human cancer cells (Zhang et al., 2006). Also, Ibrahim (2012) characterized the antibacterial agent from both methanolic flash and coelomic fluid crude extracts of sea cucumber; H. scabra using GC/MS as carotenoids and then via preparative high performance liquid chromatography (HPLC) detected them as; xanthophyll, $\beta$-crptoxanthin, and $\beta$-carotene in of $H$. scabra. Observably, the antimicrobial properties of sea cucumbers have been linked to the presence of a wide array of bioactive substances especially triterpene glycosides (saponins), chondroitin sulfates, glycosaminoglycan (GAGs), sulfated polysaccharides, sterols (glycosides and sulfates), phenolics, cerberosides, lectins, peptides, glycoprotein, glycosphingolipids, terpenoids and essential fatty acids (Bordbar et al., 2011).

The tetraterpenoid nature of palmitate and the fatty nature of oleic acid showed antimicrobial activity against both Gram-positive and G-negative organisms (Plaza et al., 2010). Finally, several of these compounds exhibited moderate cytotoxic and antibacterial activities against Gram-positive strains (Lee et al., 2012).

\section{CONCLUSION}

Data obtained from the present study demonstrated that the marine sponges and sea cucumber are a promising source of new bioactive substances. Asa well as, the inhibition efficiency of different crude extracts against several human pathogens such; $S$. aureus, E. faecalis, P. aeruginosa, and E. coli suggests promising applications in the clinical field. Furthermore, the inhibitory effect of the sea cucumber extracts against fish pathogens such as $A$. hydrophila suggests promising applications in the aquaculture field.

\section{ACKNOWLEDGEMENT}

The authors are grateful and thankful to Dr. Hamdy Ahmed; Marine Invertebrates Department, National Institute of Oceanography and Fisheries (NIOF), Alexandria, Egypt, for helping in scientific identification of the collected organisms. 


\section{REFERENCES}

Abou-Elela, G.M.; Abd-EInaby, H.; Ibrahim, H.A.H. and Okbah, M.A. (2009). Marine natural products and their potential applications as anti-infective agents. W. Appl. Sci. J., 7(7): 872-880.

Abubakar, L.; Mwangi, C.; Jacquiline-Uku, J. and Ndirangu, S. (2012). Antimicrobial activity of various extracts of the sea urchin Tripneustes gratilla (Echinoidea). Afr. J. Pharmacol. Ther., 1(1): 19-23.

Althunibat, O.Y.; Hashim, R.B.; Taher, M.; Daud, J.M.; Ikeda, M.A. and Zali, B.I. (2009). In vitro antioxidant and antiproliferative activities of three Malaysian sea cucumber species. Eur. J. Sci. Res., 37(3): 376-387.

Amer, M.S. and Ibrahim, H.A.H. (2019). Chitosan from marine-derived Penicillum spinulosum MH2 cell wall with special emphasis on its antimicrobial and antifouling properties. Egy. J. Aqua. Res., 45: 359-365.

Atlas, R.M. (1997). Handbook of media for environmental microbiology (p. 265, 412). Boca Raton, FL: CR Press.

Beauregard, K.A.; Truong, N.T.; Zhang, H.Y.; Lin, W.Y. and Beck, G. (2001). The detection and isolation of a noval antimicrobial peptide from the echinoderm, Cucumaria frondosa. Adv. Exp. Med. Biol., 484: 52-62.

Bordbar, S.; Anwar, F. and Saari, N. (2011). High-value components and bioactivities from sea cucumbers for functional foods. Mar. Drugs, 9: 1761-1805.

Bull, A.T. and Stach, J.E.M. (2007). Marine actinobacteria: new opportunities for natural product search and discovery. Trends Microbiol., 15(11): 491-499.

Casas, S.M.; Comesana, P.; Cao, A. and Villalba, A. (2011). Comparison of antibacterial activity in the hemolymph of marine bivalves from Galicia (NW Spain). J. Inverteb. Pathol., 106: 343-345.

Chen, J. (2003). Overview of sea cucumber farming and sea ranching practices in China. SPC Beche-de-mer Inf. Bull., 18:18-23.

Clark, D.P.; Carrol, J.; Naylor, S. and Crews, P. (1998). An antifungal cyclodepsipeptide, cyclolithistide A, from the sponge Theonella swinhoei. J. Org. Chem., 63: 8757-8763.

Dhinakaran, D.I. and Lipton, A.P. (2014). Bioactive compounds from Holothuria atra of Indian ocean. SpringerPlus, 3: 673-683.

Guinea, J; Peláez, T.; Alcalá, L. and Bouza, E. (2005). Evaluation of Czapeck agar and Sabouraud dextrose agar for the culture of airborne Aspergillus conidia. Diagn. Microbiol. Infect. Dis., 53(4): 333-334.

Haug, T.; Kjuul, A.K.; Styrvold, O.B.; Sandsdalen, E.; Olsen, M.O. and Stensvag, K. (2002). Antibacterial activity in Strongylocentrotus droebachiensis (Echinoidea), Cucumaria frondosa (Holothuroidea) and Asterias rubens (Asteroidea). J. Invert. Pathol., 81: 94-102. 
Hegde, V.R.; Chan, T.M.; Pu, H.; Gullo, V.P.; Patel, M.G.; Das, P.; Wagner, N.; Parameswaran, P.S. and Naik, C.G. (2002). Two selective novel triterpene glycosides from sea cucumber, Telenota Ananas: inhibitors of chemokine receptor-5. Bioorg. Med. Chem. Lett., 12: 3203-3205.

Hu, Y.; Chen, J.; Hu, G.; Yu, J.; Zhu, X.; Lin, Y.; Chen, S. and Yuan, J. (2015). Statistical research on the bioactivity of new marine natural products discovered during the 28 years from 1985 to 2012 . Mar. Drugs, 13: 202-221.

Hussein, H.M.; Hameed, I.H. and Ibraheem, O.R. (2016). Antimicrobial activity and spectral chemical analysis of methanolic leaves extract of Adiantum capillusveneris using GC-MS and FTIR spectroscopy. Int. J. Pharmacog. Phytochem. Res., 8(3): 369-385.

Ibrahim, H.A.H. (2012). Antibacterial carotenoids of three Holothuria species in Hurghada, Egypt. Egy. J. Aqua. Res., 38: 185-194.

Ibrahim, H.A.H. and Abd El-Naby, F. (2010). Antimicrobial characteristics of marine polychaetes collected from Alexandria beaches. Egy. J. Aqua. Res., 36(4): 557567.

Ibrahim, H.A.H.; Ahmed, H.O.; Abd El Razek, F.A. and Elmasry, E. (2018). Proteolysis and heat-sensitive antibacterial agents from several levantine sponge species. Int. J. Adv. Res., 6(2): 14-27.

Ibrahim, H.A.H.; Mohamed, S.Z.; El-Regal, M. and Zaki, F.A.M. (2012). Antibacterial activity of some Red Sea soft corals, Egypt. Blue Biotechnol. J., 1(4): 497-516.

Ioizzi, M.; DeMarino, S. and Zollo, F. (2001). Steroidal oligoglycosides from the asteroidae. Curr. Org. Chem., 5: 951-973.

Jawahar, A.T.; Nagarajan, J. and Shanmugam, S.A. (2002). Antimicrobial substances of potential biomedical importance from holothurian species. IJMS, 2: 161-164.

Kelly, M.S. (2005). Echinoderms: their culture and bioactive compounds. Prog. Mol. Subcell. Biol., 39: 139-165.

Khan, Z.A.; Siddiqui, M.F. and Park, S. (2019). Current and emerging methods of antibiotic susceptibility testing. Diagnostics (Basel). Jun; 9(2): 49

Kim, S.K. and Dewapriya, P. (2012). Bioactive compounds from marine sponges and their symbiotic microbes: a potential source of nutraceuticals. Adv. Food Nutr. Res., 65: 137-151.

Laport, M.S.; Marinho, P.R.; Santos, O.C.; de Almeida, P.; Romanos, M.T.; et al. (2012). Antimicrobial activity of marine sponges against coagulase-negative staphylococci isolated from bovine mastitis. Vet. Microbiol., 155: 362-368.

Lee, Y.; Jang, K.H.; Jeon, J.E.; Yang, W.Y.; Sim, C.J.; et al. (2012). Cyclic Bis1,3dialkylpyridiniums from the sponge Haliclona sp. Mar. Drugs, 10: 2126-2137.

Leonard, L.A.; Strandberg, J.D. and Winkelstein, J.A. (1990). Complement-like activity in the sea star, Asterias forbesi. Dev. Comp. Immunol., 14: 19-30. 
Marmouzia, I.; Tamsourib, N.; El Hamdanic, M.; Attard, A.; Kharbache, M.; Alamia, R.; El Jemlia, M.; Cherraha, Y.; Ebadag,h, S.S. and Faouzi, M.E.A. (2018). Pharmacological and chemical properties of some marine echinoderms. Revista Brasileira de Farmacognosia, 28: 575-581.

Matsunaga, S.; Fusetani, N.; Hashimoto, K. and Walchli, M. (1989). Theonellamide F: a novel antifungal bicyclic peptide from a marine sponge Theonella sp. J. Amer. Chem. Soc., 111: 2582- 2588.

Mayer, A.M.S.; Rodriguez, A.D.; Berlinck, R.G.S. and Hamann, M.T. (2007). Marine pharmacology in 2003-4: marine compounds with anthelmintic, antibacterial, anticoagulant, antifungal, anti-inflammatory, antimalarial, antiplatelet, antiprotozoal, antituberculosis, and antiviral activities; affecting the cardiovascular, immune and nervous systems, and other miscellaneous mechanisms of action. Comp. Biochem. Physiol., Part C145: 553-581.

Mokhlesi, A.; Saeidnia, S.; Gohari, A.R.; Mollazadeh-Moghaddam, A.R.S.K. and Es'haghi, N. (2011). Antibacterial, antifungal and cytotoxic activities of Bohadschia marmorata, a sea cucumber from north coastal of Persian Gulf. Pharmacol., Online 3: 1029-1038.

Moustafa, M.F.M.; Alamri, S.A.; Taha, T.H. and Alrumman, S.A. (2013). In vitro antifungal activity of Argemone ochroleuca Sweet latex against some pathogenic fungi. Afri. J. Biotechnol., 12(10): 1132-1137.

Muthulakshmi, A.; Jothibai, M.R. and Mohan, V.R. (2012). GC-MS analysis of bioactive components of Feronia elephantum Correa (Rutaceae). J. Appl. Pharmaceut. Sci., 2(2): 69-74.

Otero-González, A.J.; Magalhães, B.S.; Garcia-Villarino, M.; López-Abarrategui, C.; Sousa, D.A. and Dias, O.L.F.S.C. (2010). Antimicrobial peptides from marine invertebrates as a new frontier for microbial infection control. FASEB J., 24: 1324-1334.

Perdicaris, S.; Vlachogianni, T. and Valavanidis, A. (2013). Bioactive natural substances from marine sponges: new developments and prospects for future pharmaceuticals. Nat. Prod. Chem. Res., 1(3): 3-8.

Plaza, M.; Santoyo, S.; Jaimeb, L.; Reinac, G.G-B.; Herrero, M.; Senorans, F.J. and Ibanez, E. (2010). Screening for bioactive compounds from algae. J. Pharm. Biomed. Anal., 51 (2): 450-455.

Ryu, D.; Matsunaga, S. and Fusetani, N. (1994). Discodermins F-H, cytotoxic and antimicrobial tetradecapeptides from the marine sponge Discodermia kiiensis: structure revision of discodermins A-D. Tetrahedron, 50: 13409-13416.

Shaaban, M.T.; Ibrahim, H.A.H. and Hanafi, A.A.M. (2020). Antibiotic-resistant bacteria isolated from selected urine and stool human specimens. Biosci Res., 17(1): 351-365. 
Shen, S.; Liu, D.; Wei, C.; Proksch, P. and Lin, W. (2012). Purpuroines A-J, halogenated alkaloids from the sponge Iotrochota purpurea with antibiotic activity and regulation of tyrosine kinases. Bioorg. Med. Chem., 20: 6924-6928.

Wright, A.D.; McCluskey, A.; Robertson, M.J.; MacGregor, K.A.; Gordon, C.P., et al. (2011). Anti-malarial, anti-algal, anti-tubercular, anti-bacterial, antiphotosynthetic, and anti-fouling activity of diterpene and diterpene isonitriles from the tropical marine sponge Cymbastela hooperi. Org. Biomol. Chem., 9: 400-407.

Wu, J.T.; Chiang, Y.R.; Huang, W.Y. and Jane, W.Y. (2006). Cytotoxic effects of free fatty acids on phytoplankton algae and cyanobacteria. Aquat. Toxicol., 80: 338-345.

Yang, F.; Hamann, M.T.; Zou, Y.; Zhang, M.Y.; Gong, X.B., et al. (2012). Antimicrobial metabolites from the Paracel Islands sponge Agelas mauritiana. J. Nat. Prod., 75: 774-778.

Youssef, D.; Shaala, L. and Asfour, H. (2013). Bioactive compounds from the Red Sea marine sponge Hyrtios species. Mar. Drugs, 11(4): 1061-1070.

Zhang, S.-Y.; Yi, Y.-H. and Tang, H.-F. (2006). Bioactive triterpene glycosides from the sea cucumber Holothuria fuscocinerea. J. Nat. Prod., 69(10): 1492-1495.

Zou, Z.; Yi, Y.; Wu, H.; Yao, L. and Jiuhong, L.D. (2005) Intercedensides D-I, cytotoxic triterpene glycosides from the sea cucumber Mensamaria intercedens Lampert. J. Nat. Prod., 68(4): 540-546. 